\title{
A Study to Assess the Effect of Therapeutic Positions on Hemodynamic Parameters among Critically Ill Patients in the Intensive Care Unit at Sri Ramachandra Medical Centre \\ A Mercy Anchala* \\ SRM University, Kattankulathur, Chennai, India
}

\begin{abstract}
Positioning is one of the most frequently performed nursing activities in the critical care, often providing a central pivotal focus for planning other nursing activities. Currently, the concept of therapeutic positioning is emerging in trauma and critical care with the adaptation of research based positioning strategies designed to enhance or promote physiologic stability and tolerance of nursing and medical treatments. The study was aimed to determine the effect of therapeutic positions on hemodynamic parameters among critically ill patients. Experimental pre-test - post-test design was used. Samples were critically ill patients who got admitted in the C4 multi-disciplinary intensive care unit of Sri Ramachandra Medical Centre. Simple random sampling was used to select 40 samples. Hemodynamic parameters such as heart rate, respiratory rate, systolic blood pressure, diastolic blood pressure, oxygen saturation, mean arterial pressure and the background variables of critically ill patients were studied together. Positioned the patients on various therapeutic positions for every two hours by following turning schedule such as left lateral, supine, right lateral, supine and semi fowler's position was carried out for the study group patients, whereas the control group received the routine care. Hemodynamic parameters were assessed before and after the positioning for both the groups for three days. There was a significant difference in systolic blood pressure in left lateral position at (t value 3.317 ) $p<0.01$ and oxygen saturation in semi fowler's position ( $t$ value 9.211 ) $p<0.001$. This study has attempted to identify the changes in hemodynamic parameters among critically ill patients while following turning schedule. The study shows that there was a significant difference in systolic blood pressure in left lateral position and oxygen saturation in semi fowler's position. Therapeutic positions based on turning schedule have a significant role in maintaining the hemodynamic parameters and preventing complications.
\end{abstract}

Keywords: Hemodynamic parameters; Therapeutic positions; Critically ill patients

\section{Introduction}

Hemodynamic instability is the main reason why critically ill patients stay in the supine position for extended periods. After a change in the body's gravitational plane, the cardiovascular system tries to adjust in two ways:

- The shift in plasma volume may send messages to the autonomic nervous system telling it to change the vascular tone.

- An inner ear or vestibular response affects the cardiovascular system.

Repositioning is conceptualized as turning the patient from side to side when lying in bed or on a similar surface. Healthy individuals change positions, even during sleep, approximately every $12 \mathrm{~min}$. A variety of sensory cues prompt a change in body position. These sensory cues prevent detrimental effects of prolonged periods of immobility. Individuals who have neurological impairments must rely on others to reposition them to prevent hazards of immobility. Nurses use clinical judgment based on physiological and scientific evidence to position critically ill patients to prevent complications of immobility and to achieve optimal patient outcomes. Therapeutic positioning in stationary positions is done to optimize ventilation and perfusion and to promote effective pulmonary gas exchange.

For a large number of patients, turning them every two hours is not enough to preserve the oxygenating ability of the lungs or to prevent pneumonia.

Khurana states about the net effects which occur on the cardiovascular system on rising from the supine to upright position after the compensatory mechanism as [1]:

- Central venous pressure is decreased slightly $(3 \mathrm{~mm} \mathrm{Hg})$
- Heart rate is increased by $25 \%$

- Stroke volume is decreased by $40 \%$

- Cardiac output is decreased by $25 \%$

- Total peripheral resistance is increased by $25 \%$

- Systolic blood pressure is slightly reduced due to fall in stroke volume

- Diastolic blood pressure is slightly increased due to increased total peripheral resistance

- Pulse pressure is reduced

- Mean arterial pressure is nearly unchanged

Critically ill patients commonly have poor vascular tone, a dysfunctional autonomic feedback loop, or low cardiovascular reserve. Also, they have established equilibrium in a single position over time.

Repositioning is conceptualized as turning the patient from side to side when lying in bed or on a similar surface. Healthy individuals change positions, even during sleep, approximately every $12 \mathrm{~min}$. A variety of sensory cues prompt a change in body position. These

*Corresponding author: A Mercy Anchala, SRM University, Kattankulathur Chennai, India, Tel: +919790072234; E-mail: mercyanchala@gmail.com

Received March 29, 2016; Accepted May 26, 2016; Published June 02, 2016

Citation: Anchala AM (2016) A Study to Assess the Effect of Therapeutic Positions on Hemodynamic Parameters among Critically III Patients in the Intensive Care Unit at Sri Ramachandra Medical Centre. J Nurs Care 5: 348. doi:10.4172/21671168.1000348

Copyright: () 2016 Anchala AM. This is an open-access article distributed under the terms of the Creative Commons Attribution License, which permits unrestricted use, distribution, and reproduction in any medium, provided the original author and source are credited. 
sensory cues prevent detrimental effects of prolonged periods of immobility. Individuals who have neurological impairments must rely on others to reposition them to prevent hazards of immobility. Nurses use clinical judgment based on physiological and scientific evidence to position critically ill patients to prevent complications of immobility and to achieve optimal patient outcomes. Therapeutic positioning in stationary positions is done to optimize ventilation and perfusion and to promote effective pulmonary gas exchange.

Positioning is one of the most frequently performed nursing activities in the critical care, often providing a central pivotal focus for planning other nursing activities. Currently, the concept of therapeutic positioning is emerging in trauma and critical care with the adaptation of research based positioning strategies designed to enhance or promote physiologic stability and tolerance of nursing and medical treatments.

Fontaine suggested that positioning may be related to multisystem consequences including altered hemodynamics, impaired gas exchange, changes in cerebral tissue perfusion, and increases in intracranial pressure [2].

Intensive care units are designed to meet the special needs of acutely and critically ill patients being physiologically unstable, requiring advanced and sophisticated judgments by the nurses and physician.

Majority of ICU patients are limited in overall physical mobility, resulting in decreased ability to change their position in bed and thus increasing risk of prolonged and intense pressure. For a number of years, nurses have recognized that positioning prevents skin breakdown, mobilizes secretions and provides comfort without identifying the impact that different types of positioning strategies have on pulmonary gas exchange, ventilator weaning outcomes and the prevention of deconditioning in survivors of ICU care. The importance of positioning as a priority of practice is challenged in a high technology based environment. Critical care nursing has a problem and the solution rests in increasing the awareness of the importance of positioning on short and long term patient outcomes.

The solution is to improve nurses' awareness of the importance of proper positioning on both short- and long-term patient outcomes [3]. Thus the investigator felt the need to conduct the study to assess the effect of therapeutic positions on hemodynamic parameters among critically ill patients.

\section{Materials and Methods}

The research design utilized for the study was experimental pre-test - post-test design. The setting of the study was C4 multi-disciplinary intensive care unit which is situated in the fourth floor of Sri Ramachandra Medical Centre, Porur, Chennai, Tamil Nadu, India from a period of one month (10.06.2012 to 10.07.2012). C4 multi-disciplinary Intensive Care Unit is equipped with sophisticated technology with 27 beds which admit patients with multispecialty critical problems.

A total of 40 sample both male and female patients who were critically ill during the study period were selected. All patients who fulfilled the inclusion criteria were randomized by lottery method to assign the group. 40 lots were prepared by the investigator in which 20 lots were labelled as study group and 20 were labelled as control group. The patients were assigned either to the study or the control group based on the lot labelled as either study or control group which was picked up by the patient from the box.

Tool consisted of two parts. Section A: Demographic variables consist of age, gender, education, occupation, family income, residence and education and Clinical variables consist of duration of ICU stay, medication and body mass index. Section B: Hemodynamic parameters such as heart rate, respiratory rate, systolic blood pressure, diastolic blood pressure, oxygen saturation and mean arterial pressure. Content validity was obtained from nursing experts from within and outside the college. Same monitor was used to read the hemodynamic parameters.

A written permission to conduct the study was obtained from The Chairman, Nursing Education and the Head of the department, Department of anesthesiology, C4 multi-disciplinary intensive care unit, SRMC. Informed consent obtained from the study participants. Data collection format was formulated and it comprised of background variables and the hemodynamic parameters. According to the inclusion and exclusion criteria patients were selected. They were assigned randomly either to the study or to the control group depending on the lot selected by the patient from the box. Positioned the patients on various therapeutic positions for every two hours by following turning schedule such as left lateral, supine, right lateral, supine and semi fowler's position was carried out for the study group patients, whereas the control group received the routine care.

Hemodynamic parameters were assessed before and after the positioning for both the groups. The intervention was carried out for three days to the study group and both the groups were followed for three days. After completing the data collection, data was coded, verified, and transferred into a special form to be suitable for computer feeding using SPSS (Statistical Package for Social Science) version 17.0. To utilize for data entry, statistical analysis and presentation of the results. Descriptive measures include means and standard deviations for quantitative variables. Analysis of collected data was done through the use of several statistical tests as: student $t$ test that is used to test the association between two variables. For each test the $P$ value of 0.05 level was used as the cut off value for statistical significance.

\section{Results}

Analysed data are presented in the following sections:

Section A: Percentage distribution of the background variables of the critically ill patients.

Section B: Comparison of hemodynamic parameters between the study and control group

Section C: Comparison of hemodynamic parameters within the study and control group.

Section D: Comparison of hemodynamic parameters in post-test among study and control group in various therapeutic positions

Section E: Association of selected background variables with hemodynamic parameters of patients in the study group and control group.

\section{Discussion}

The first objective of the study was to assess the hemodynamic parameters on various therapeutic positions among critically ill patients.

To assess the hemodynamic parameters among critically ill patients who received therapeutic positions for three days, assessment data of hemodynamic parameters such as heart rate, respiratory rate, systolic blood pressure, diastolic blood pressure, mean arterial pressure and oxygen saturation were measured from monitors before and after the positioning. Table 1-3 depicts the mean value and standard deviation of hemodynamic parameters in pre-test and post-test among critically ill patients between the study and control group in left lateral position. In respect to systolic blood pressure, the overall post-test mean value 
Citation: Anchala AM (2016) A Study to Assess the Effect of Therapeutic Positions on Hemodynamic Parameters among Critically III Patients in the Intensive Care Unit at Sri Ramachandra Medical Centre. J Nurs Care 5: 348. doi:10.4172/2167-1168.1000348

Page 3 of 8

\begin{tabular}{|c|c|c|c|c|}
\hline \multirow[b]{2}{*}{ Demographic variables } & \multicolumn{2}{|c|}{ Study group $(n=20)$} & \multicolumn{2}{|c|}{ Control group $(n=20)$} \\
\hline & No. & $\%$ & No. & $\%$ \\
\hline $\begin{array}{l}\text { 1. Age in years } \\
\text { a. } 21-30 \\
\text { b. } 31-40 \\
\text { c. } 41-50 \\
\text { d. } 51-60 \\
\text { e. Above } 60\end{array}$ & $\begin{array}{l}4 \\
3 \\
2 \\
3 \\
8\end{array}$ & $\begin{array}{l}20 \\
15 \\
10 \\
15 \\
40\end{array}$ & $\begin{array}{l}1 \\
1 \\
4 \\
5 \\
9\end{array}$ & $\begin{array}{l}5 \\
5 \\
20 \\
25 \\
45\end{array}$ \\
\hline $\begin{array}{l}\text { 2. Gender } \\
\text { a. Male } \\
\text { b. Female }\end{array}$ & $\begin{array}{c}17 \\
3\end{array}$ & $\begin{array}{l}85 \\
15\end{array}$ & $\begin{array}{l}10 \\
10\end{array}$ & $\begin{array}{l}50 \\
50\end{array}$ \\
\hline $\begin{array}{l}\text { 3. Occupation } \\
\text { a. Business } \\
\text { b. Homemaker } \\
\text { c. Retired } \\
\text { d. Professional }\end{array}$ & $\begin{array}{l}10 \\
3 \\
5 \\
2\end{array}$ & $\begin{array}{l}50 \\
15 \\
25 \\
10\end{array}$ & $\begin{array}{c}5 \\
10 \\
3 \\
2\end{array}$ & $\begin{array}{l}25 \\
50 \\
15 \\
10\end{array}$ \\
\hline $\begin{array}{l}\text { 4. Family Income per } \\
\text { Month (in Rupees) } \\
\text { a. Less than } 10,000 \\
\text { b. } 10,001-20,000 \\
\text { c. } 20,001-30,000 \\
\text { d. More than } 30,000\end{array}$ & $\begin{array}{l}1 \\
6 \\
9 \\
4\end{array}$ & $\begin{array}{c}5 \\
30 \\
45 \\
20\end{array}$ & $\begin{array}{c}0 \\
0 \\
13 \\
7\end{array}$ & $\begin{array}{c}0 \\
0 \\
65 \\
35\end{array}$ \\
\hline $\begin{array}{l}\text { 5. Residence } \\
\text { a. Urban } \\
\text { b. Rural } \\
\text { c. Sub urban } \\
\end{array}$ & $\begin{array}{c}12 \\
7 \\
1\end{array}$ & $\begin{array}{c}60 \\
35 \\
5\end{array}$ & $\begin{array}{c}15 \\
1 \\
4 \\
\end{array}$ & $\begin{array}{c}75 \\
5 \\
20\end{array}$ \\
\hline $\begin{array}{l}\text { 6. Education } \\
\text { a. Illiterate } \\
\text { b. Primary } \\
\text { c. Secondary } \\
\text { d. High school } \\
\text { e. Professional }\end{array}$ & $\begin{array}{l}1 \\
5 \\
8 \\
3 \\
3\end{array}$ & $\begin{array}{c}5 \\
25 \\
40 \\
15 \\
15\end{array}$ & $\begin{array}{l}4 \\
8 \\
3 \\
3 \\
2\end{array}$ & $\begin{array}{l}20 \\
40 \\
15 \\
15 \\
10\end{array}$ \\
\hline
\end{tabular}

Table 1 reveals the percentage distribution of background variables among critically ill patients in accordance with their age, gender, education, occupation, family income per month, residence and education.

Table 1: Distribution of the demographic variables among the critically ill patients $(\mathrm{N}=40)$

\begin{tabular}{|c|c|c|c|c|}
\hline \multirow[b]{2}{*}{ Clinical variables } & \multicolumn{2}{|c|}{ Study group $(n=20)$} & \multicolumn{2}{|c|}{ Control group $(n=20)$} \\
\hline & No. & $\%$ & No. & $\%$ \\
\hline $\begin{array}{l}\text { 1. Duration of ICU stay } \\
\text { a. } 1 \text { day } \\
\text { b. } 2 \text { days } \\
\text { c. } 3 \text { days }\end{array}$ & $\begin{array}{c}18 \\
1 \\
1\end{array}$ & $\begin{array}{c}90 \\
5 \\
5\end{array}$ & $\begin{array}{c}18 \\
1 \\
1\end{array}$ & $\begin{array}{c}90 \\
5 \\
5\end{array}$ \\
\hline $\begin{array}{l}\text { 2. Medication } \\
\text { a. Antibiotics } \\
\text { b. Anticoagulants } \\
\text { c. Any other }\end{array}$ & $\begin{array}{c}19 \\
1 \\
0\end{array}$ & $\begin{array}{c}95 \\
5 \\
0\end{array}$ & $\begin{array}{l}16 \\
3 \\
1\end{array}$ & $\begin{array}{c}80 \\
15 \\
5\end{array}$ \\
\hline $\begin{array}{l}\text { 2. Body Mass Index (Weight } \\
\text { in Kg/Height in } \mathbf{~ m}^{2} \text { ) } \\
\text { a. Less than } 18 \\
\text { b. } 18.5-20 \\
\text { c. } 20.5-22 \\
\text { d. } 22.5-24 \\
\text { e. More than } 24.5\end{array}$ & $\begin{array}{l}2 \\
2 \\
1 \\
8 \\
7\end{array}$ & $\begin{array}{c}10 \\
10 \\
5 \\
40 \\
35\end{array}$ & $\begin{array}{c}1 \\
2 \\
2 \\
4 \\
11\end{array}$ & $\begin{array}{c}5 \\
10 \\
10 \\
20 \\
55\end{array}$ \\
\hline $\begin{array}{l}\text { 4. Diagnosis } \\
\text { a. Gastrointestinal disorders } \\
\text { b. Renal diseases } \\
\text { c. Neurological disorders } \\
\text { d. Diabetic ketoacidosis } \\
\text { e. Poisoning }\end{array}$ & $\begin{array}{l}6 \\
4 \\
4 \\
2 \\
4\end{array}$ & $\begin{array}{l}30 \\
20 \\
20 \\
10 \\
20\end{array}$ & $\begin{array}{l}4 \\
5 \\
4 \\
2 \\
5\end{array}$ & $\begin{array}{l}20 \\
25 \\
20 \\
10 \\
25\end{array}$ \\
\hline
\end{tabular}

Table 2 shows that $18(90 \%)$ patients stayed in the intensive care unit for one day both in the study group and control group. Regarding medications, $19(95 \%)$ patients in the study group and $16(80 \%)$ patients in the control group received antibiotics.

Table 2: Distribution of the clinical variables among the critically ill patients $(\mathrm{N}=40)$.

of the study group was 129.65 with standard deviation of 13.98 , and in the control group, the overall post-test mean value of systolic blood pressure was 144.50 with standard deviation of 14.33 .

\begin{tabular}{|l|l|c|c|c|c|c|c|}
\hline \multirow{2}{*}{$\begin{array}{l}\text { S. } \\
\text { No. }\end{array}$} & Hemodynamic & \multicolumn{2}{|c|}{ Study group } & \multicolumn{2}{c|}{ Control group } & \multirow{2}{*}{ t-test } & p-value \\
\cline { 3 - 7 } & Parameters & Mean & S.D & Mean & S.D & & \\
\hline 1. & Heart rate & 86.70 & 10.07 & 85.80 & 12.68 & 0.249 & 0.805 (N.S) \\
\hline 2. & Respiratory rate & 22.85 & 6.80 & 22.50 & 5.79 & 0.175 & 0.862 (N.S) \\
\hline 3 & Systolic blood pressure & 129.65 & 13.98 & 144.50 & 14.33 & 3.317 & $0.002^{* *}$ \\
\hline 4 & Diastolic blood pressure & 82.60 & 16.86 & 82.70 & 14.58 & 0.020 & $0.984($ N.S) \\
\hline 5 & Mean arterial pressure & 97.85 & 16.21 & 100.30 & 14.78 & 0.499 & 0.620 (N.S) \\
\hline 6 & Oxygen saturation & 95.90 & 2.07 & 95.35 & 2.36 & 0.781 & 0.440 (N.S) \\
\hline
\end{tabular}

** $\mathrm{p}<0.01$ Level of Significant

Table 3 represents the comparison of hemodynamic parameters in the posttest between the study group and control group in left lateral position. The overall mean value of systolic blood pressure in study group was 129.65 with standard deviation of 13.98 and in control group; the overall mean value of diastolic blood pressure was 144.50 with standard deviation of 14.33 . The t-value of systolic blood pressure was 3.317 , which showed that there was a statistically significant difference in the mean scores between the study group and control group in the left lateral position at $p<0.01$.

Table 3: Comparison of hemodynamic parameters in posttest between the study group and control group in left lateral position $(\mathrm{N}=40)$.

\begin{tabular}{|c|c|c|c|c|c|c|c|}
\hline \multirow[b]{2}{*}{ S. No. } & \multirow{2}{*}{$\begin{array}{l}\text { Hemodynamic } \\
\text { Parameters }\end{array}$} & \multicolumn{2}{|c|}{ Study group } & \multicolumn{2}{|c|}{ Control group } & \multirow[b]{2}{*}{ t-test } & \multirow[b]{2}{*}{$p$-value } \\
\hline & & Mean & S.D & Mean & S.D & & \\
\hline 1. & Heart rate & 87.95 & 15.45 & 85.15 & 13.50 & 0.610 & 0.545 (N.S) \\
\hline 2. & Respiratory rate & 20.10 & 5.25 & 19.20 & 5.81 & 0.514 & 0.611 (N.S) \\
\hline 3 & Systolic blood pressure & 129.15 & 16.82 & 130.40 & 16.59 & 0.237 & 0.814 (N.S) \\
\hline 4 & Diastolic blood pressure & 82.60 & 15.35 & 81.05 & 14.24 & 0.331 & 0.743 (N.S) \\
\hline 5 & Mean arterial pressure & 97.85 & 14.93 & 100.00 & 15.28 & 0.450 & 0.655 (N.S) \\
\hline 6 & Oxygen saturation & 100.00 & 0.00 & 95.20 & 2.33 & 9.211 & $0.000^{* * *}$ \\
\hline
\end{tabular}

${ }^{* * *} \mathrm{p}<0.001$ level of significance

Table 4 represents the comparison of hemodynamic parameters in the post-test between the study group and control group in semi fowler's position. The overall mean value of oxygen saturation in study group was 100.00 with standard deviation of 0.00 and in control group; the overall mean value of oxygen saturation was 95.20 with standard deviation of 2.33. The t-value of oxygen saturation was 9.211 which showed that there was a statistically significant difference in the mean scores between the study group and control group in semi fowler's position at $p<0.001$.

Table 4: Comparison of hemodynamic parameters in post-test between the study group and control group in semi fowler's position $(\mathrm{N}=40)$.

Table 4 depicts the mean value and standard deviation of hemodynamic parameters in pre-test and post-test among critically ill patients between study and control group in semi fowler's position. With respect to oxygen saturation, the overall post-test mean value of study group was 100.00 with standard deviation of 0.00 , and in the control group, the overall post-test mean value of oxygen saturation was 95.20 with standard deviation of 2.33 .

The findings revealed that there was a significant increase in oxygen saturation in semi fowler's position and also there was a significant difference in blood pressure in left lateral position. These findings were similar to the study conducted by Aries and his team. Researchers studied the variations of blood pressure in stroke unit patients that result from alternating body positions. BP was measured in both arms in the (back) supine and both lateral decubitus positions. In total, 54 consecutive acute stroke patients were included. Thirty-five patients had right-sided deficits and 19 patients had left-sided deficits. Supine $\mathrm{BP}$ readings were similar in the right and left arms regardless of the side of deficit. Measurements of BP in the lateral decubitus positions resulted in significantly lower BP readings in the uppermost arm (around $12 \mathrm{~mm} \mathrm{Hg}$ in both arms) and significantly higher readings in the right lowermost arm (around $6 \mathrm{~mm} \mathrm{Hg}$ ) compared to the supine position. This effect seemed less pronounced when the left lowermost arm was measured. There was no relation between the change of BP readings in various lateral positions and affected side after stroke. 
The second objective of the study was to determine the effect of therapeutic positions on the hemodynamic parameters among critically ill patients.

The analysis of measured value of heart rate, respiratory rate, systolic blood pressure, diastolic blood pressure, mean arterial pressure and oxygen saturation were represented as tables and figures and independent $t$ test was applied to test the significance of the difference. The analysis of hemodynamic parameters (Table 3) represents the comparison of parameters in post-test between the study group and control group in left lateral position. In systolic blood pressure there was a significant difference in the mean scores between the study group and control group in the left lateral position ( $t$ value 3.317 ) at $\mathrm{p}<0.01$.

Table 4 represents the comparison of hemodynamic parameters in post-test between the study group and control group in semi fowler's position. The $t$-value of oxygen saturation was 9.211 , which showed that there was a highly significant difference in the mean scores between the study group and control group in semi fowler's position at $\mathrm{p}<0.001$.

Table 5 depicts the comparison of hemodynamic parameters between the pre-test and post-test within the study group in right lateral position. In pre-test, the overall mean value of oxygen saturation in the study group was 94.90 with standard deviation of 1.55 , and in post-test it was 96.30 with standard deviation of 1.94. Analysis revealed the paired t-value of oxygen saturation to be 3.074, which showed that there was a statistically significant difference in the mean scores between pre-test and post-test within the study group in right lateral position at $\mathrm{p}<0.05$.

Table 6 represents the comparison of hemodynamic parameters between pre-test and post-test within the study group in semi fowler's position. In pre-test, the overall mean value of oxygen saturation in the study group was 96.60 with standard deviation of 1.63 , and in posttest it was 100.00 with standard deviation of 0.00 . Analysis revealed the paired t-value of oxygen saturation as 9.299 , which showed the presence of a statistically significant difference in the mean scores between the pre-test and post-test within the study group in semi fowler's position at $\mathrm{p}<0.001$.

Table 7 represents the comparison of hemodynamic parameters between pre-test and post-test within the control group in left lateral position. In pre-test, the overall mean value of systolic blood pressure in control group was 136.80 with standard deviation of 22.79 , and in posttest it was 144.50 with standard deviation of 14.33. Analysis revealed the paired t-value of systolic blood pressure as 3.032, which showed a statistically significant difference in the mean scores between the pretest and post-test within the control group in the left lateral position at $\mathrm{p}<0.05$.

Table 8 revealed the $\mathrm{F}$ value of all the hemodynamic parameters, which showed that there was a statistically significant difference in the post-test mean scores of oxygen saturation among the study group in all the positions at $\mathrm{p}<0.001$.

Table 9 revealed the $\mathrm{F}$ value of all the hemodynamic parameters, which showed that there was a statistically significant difference in the post-test mean scores of systolic blood pressure among the control group in all the positions at $\mathrm{p}<0.01$.

The findings revealed that there was a significant change in hemodynamic parameters in various therapeutic positions. These findings were similar to the study conducted by Burns and his team. Researchers studied the effect of body position on spontaneous respiratory rate and tidal volume in patients with obesity, abdominal distension and ascites to determine the body position that optimizes

\begin{tabular}{|c|c|c|c|c|c|c|c|}
\hline \multirow{2}{*}{ S. No. } & \multirow{2}{*}{ Hemodynamic Parameters } & \multicolumn{2}{|c|}{ Pre-test } & \multicolumn{2}{|c|}{ Post-test } & \multirow{2}{*}{ Paired t-test } & \multirow{2}{*}{ p-value } \\
\hline & & Mean & S.D & Mean & S.D & & \\
\hline 1. & Heart rate & 88.80 & 15.14 & 86.60 & 9.51 & 0.578 & 0.570 (N.S) \\
\hline 2. & Respiratory rate & 24.95 & 5.88 & 21.15 & 5.95 & 1.837 & 0.082 (N.S) \\
\hline 3 & Systolic blood pressure & 131.80 & 20.50 & 130.90 & 13.52 & 0.250 & 0.805 (N.S) \\
\hline 4 & Diastolic blood pressure & 77.75 & 18.60 & 84.50 & 15.93 & 2.125 & 0.047 (N.S) \\
\hline 5 & Mean arterial pressure & 95.50 & 17.56 & 99.50 & 14.60 & 1.324 & 0.201 (N.S) \\
\hline 6 & Oxygen saturation & 94.90 & 1.55 & 96.30 & 1.94 & 3.074 & $0.006^{*}$ \\
\hline
\end{tabular}

${ }^{*} \mathrm{p}<0.05$ level of significance

Table 5 represents the comparison of hemodynamic parameters between the pre-test and post-test within the study group in right lateral position. In pretest, the overall mean value of oxygen saturation in study group was 94.90 with standard deviation of 1.55 , and in post-test it was 96.30 with standard deviation of 1.94 . Analysis revealed the paired t-value of oxygen saturation to be 3.074 , which showed that there was a statistically significant difference in the mean scores between pretest and posttest within the study group in right lateral position at $p<0.05$.

Table 5: Comparison of hemodynamic parameters within the study group in right lateral position $(n=20)$.

\begin{tabular}{|c|c|c|c|c|c|c|c|}
\hline \multirow{2}{*}{ S. No. } & \multirow{2}{*}{$\begin{array}{l}\text { Hemodynamic } \\
\text { Parameters }\end{array}$} & \multicolumn{2}{|c|}{ Pre-test } & \multicolumn{2}{|c|}{ Post-test } & \multirow{2}{*}{ Paired t-test } & \multirow{2}{*}{ p-value } \\
\hline & & Mean & S.D & Mean & S.D & & \\
\hline 1. & Heart rate & 88.40 & 16.43 & 87.95 & 15.45 & 0.096 & 0.925 (N.S) \\
\hline 2. & Respiratory rate & 23.10 & 5.28 & 20.10 & 5.25 & 1.893 & 0.074 (N.S) \\
\hline 3 & Systolic blood pressure & 130.90 & 16.81 & 129.15 & 16.82 & 0.415 & 0.683 (N.S) \\
\hline 4 & Diastolic blood pressure & 74.90 & 15.90 & 82.60 & 15.35 & 2.402 & 0.027 (N.S) \\
\hline 5 & Mean arterial pressure & 94.45 & 15.70 & 97.85 & 14.93 & 1.187 & 0.250 (N.S) \\
\hline 6 & Oxygen saturation & 96.60 & 1.63 & 100.00 & 0.00 & 9.299 & $0.000^{\star * *}$ \\
\hline
\end{tabular}

${ }^{* * *} p<0.001$ level of significance

Table 6 represents the comparison of hemodynamic parameters between pre-test and post-test within the study group in semi fowler's position. In pretest, the overall mean value of oxygen saturation in study group was 96.60 with standard deviation of 1.63 , and in post-test it was 100.00 with standard deviation of 0.00 . Analysis revealed the paired t-value of oxygen saturation as 9.299 , which showed that there was a statistically significant difference in the mean scores between pretest and posttest within the study group in semi fowler's position at $p<0.001$.

Table 6: Comparison of hemodynamic parameters within the study group in semi fowler's position $(n=20)$. 
Citation: Anchala AM (2016) A Study to Assess the Effect of Therapeutic Positions on Hemodynamic Parameters among Critically III Patients in the Intensive Care Unit at Sri Ramachandra Medical Centre. J Nurs Care 5: 348. doi:10.4172/2167-1168.1000348

Page 5 of 8

\begin{tabular}{|c|c|c|c|c|c|c|c|}
\hline \multirow{2}{*}{ S. No. } & \multirow{2}{*}{ Hemodynamic Parameters } & \multicolumn{2}{|c|}{ Pre-test } & \multicolumn{2}{|c|}{ Post-test } & \multirow{2}{*}{ Paired t-test } & \multirow{2}{*}{ p-value } \\
\cline { 3 - 8 } & Mean & S.D & Mean & S.D & 12.68 & 1.148 & 0.265 (N.S) \\
\hline 1. & Heart rate & 90.55 & 17.98 & 85.80 & 5.79 & 0.628 & 0.537 (N.S) \\
\hline 2. & Respiratory rate & 23.50 & 6.67 & 22.50 & 14.33 & 3.032 & $0.007^{*}$ \\
\hline 3 & Systolic blood pressure & 136.80 & 22.79 & 144.50 & 14.58 & 0.257 & 0.800 (N.S) \\
\hline 4 & Diastolic blood pressure & 83.40 & 18.11 & 82.70 & 14.78 & 0.362 & 0.721 (N.S) \\
\hline 5 & Mean arterial pressure & 101.25 & 18.47 & 100.30 & 2.36 & 0.691 & 0.498 (N.S) \\
\hline 6 & Oxygen saturation & 94.80 & 2.70 & 95.35 & & \\
\hline
\end{tabular}

${ }^{*} p<0.05$ level of significance

Table 7 represents the comparison of hemodynamic parameters between pre-test and post-test within the control group in left lateral position. In pre-test, the overall mean value of systolic blood pressure in control group was 136.80 with standard deviation of 22.79 , and in post-test it was 144.50 with standard deviation of 14.33 . Analysis revealed the paired t-value of systolic blood pressure as 3.032, which showed that there was a statistically significant difference in the mean scores between pretest and posttest within the control group in left lateral position at $p<0.05$.

Table 7: Comparison of hemodynamic parameters within the control group in left lateral position $(n=20)$.

\begin{tabular}{|c|c|c|c|c|c|c|c|c|c|c|}
\hline \multirow{2}{*}{ S. No. } & \multirow{2}{*}{$\begin{array}{l}\text { Hemodynamic } \\
\text { Parameters }\end{array}$} & \multicolumn{2}{|c|}{ Supine } & \multicolumn{2}{|c|}{ Left lateral } & \multicolumn{2}{|c|}{ Right lateral } & \multicolumn{2}{|c|}{ Semi fowler's } & \multirow{2}{*}{$\begin{array}{c}F \text { value and } P \\
\text { value }\end{array}$} \\
\hline & & Mean & S.D & Mean & S.D & Mean & S.D & Mean & S.D & \\
\hline 1. & Heart rate & 87.3 & 11.31 & 86.7 & 10.07 & 86.6 & 9.51 & 87.95 & 15.45 & $0.056,0.983$ \\
\hline 2. & Respiratory rate & 22.75 & 4.78 & 22.85 & 6.80 & 21.15 & 5.95 & 20.10 & 525 & $1.068,0.368$ \\
\hline 3 & Systolic blood pressure & 140.80 & 17.92 & 129.65 & 13.98 & 130.9 & 13.52 & 129.15 & 16.82 & $2.463,0.069$ \\
\hline 4 & Diastolic blood pressure & 81.40 & 15.73 & 82.60 & 16.86 & 84.5 & 15.93 & 82.6 & 15.35 & $0.129,0.943$ \\
\hline 5 & Mean arterial pressure & 101.55 & 15.26 & 97.85 & 16.21 & 99.5 & 14.6 & 97.85 & 14.93 & $0.265,0.850$ \\
\hline 6 & Oxygen saturation & 95.80 & 1.98 & 95.9 & 2.07 & 96.3 & 1.94 & 100.00 & 0.00 & $27.048,0.000^{* * *}$ \\
\hline
\end{tabular}

${ }^{* * *} \mathrm{p}<0.001$ level of significance

Table 8 depicts the comparison within the study group between various positions showed a statistical significance for oxygen saturation at $p<0.001$. Other parameters did not show any significant difference at $p<0.001$

Table 8: Comparison of hemodynamic parameters in post-test among study group in various therapeutic positions $(n=20)$.

\begin{tabular}{|c|c|c|c|c|c|c|c|c|c|c|}
\hline \multirow{2}{*}{ S. No. } & \multirow{2}{*}{$\begin{array}{l}\text { Hemodynamic } \\
\text { Parameters }\end{array}$} & \multicolumn{2}{|c|}{ Supine } & \multicolumn{2}{|c|}{ Left lateral } & \multicolumn{2}{|c|}{ Right lateral } & \multicolumn{2}{|c|}{ Semi fowler's } & \multirow{2}{*}{$\begin{array}{c}F \text { value and } P \\
\text { value }\end{array}$} \\
\hline & & Mean & S.D & Mean & S.D & Mean & S.D & Mean & S.D & \\
\hline 1. & Heart rate & 86.10 & 13.95 & 85.50 & 12.68 & 84.95 & 15.07 & 85.15 & 13.5 & $0.031,0.993$ \\
\hline 2. & Respiratory rate & 23.20 & 5.79 & 22.50 & 5.79 & 23.25 & 6.04 & 19.2 & 5.81 & $2.154,0.100$ \\
\hline 3 & Systolic blood pressure & 141.0 & 19.40 & 144.5 & 14.33 & 129.35 & 16.66 & 130.4 & 16.59 & $4.053,0.010^{* *}$ \\
\hline 4 & Diastolic blood pressure & 82.05 & 12.20 & 82.70 & 14.58 & 76.95 & 14.54 & 81.05 & 14.24 & $0.688,0.562$ \\
\hline 5 & Mean arterial pressure & 101.7 & 13.18 & 100.3 & 14.78 & 95.10 & 14.26 & 100.0 & 15.28 & $0.801,0.497$ \\
\hline 6 & Oxygen saturation & 94.95 & 2.54 & 95.35 & 2.36 & 95.70 & 3.24 & 95.2 & 2.33 & $0.281,0.839$ \\
\hline
\end{tabular}

${ }^{* *} p<0.01$ level of significant

Table 9 depicts the comparison within the control group between various positions showed a statistical significance for systolic blood pressure at $p<0.01$. Other parameters did not show any significant difference at $p<0.01$.

Table 9: Comparison of hemodynamic parameters in post-test among control group in various therapeutic positions $(n=20)$.

breathing pattern (tidal volume and respiratory rate) in spontaneously breathing, intubated patients with a large abdomen. Nineteen intubated patients with abdominal distension, ascites or obesity who were on continuous positive airway pressure or the pressure support ventilation mode were studied in the 0 degrees, 45 degrees, 90 degrees and reverse Trendelenburg's at 45 degrees positions for 5 min prior to data collection. They concluded that 45 degrees position resulted in a significantly larger tidal volume and lower respiratory rate than the 90 degrees position in intubated, spontaneously breathing patients with a large abdomen. The 45 degrees position resulted in a significantly lower respiratory rate than that at 90 degrees; however, no difference in tidal volume was demonstrated (Tables 10-13).

Another study was conducted by Kim. They studied the effects of semi fowler's position on post-operative recovery in recovery room for patients with laparoscopic abdominal surgery. The research was performed by non-equivalent control group non-synchronized quasi-experimental design. The subjects were forty patients who had laparoscopic abdominal surgery in a hospital from August through November of 2003. Post-recovery scores were measured.
The experimental group was placed in semi fowler's position while the control group was placed in supine position. The patients in the experimental group placed in semi fowler's position showed significant higher post-recovery scores than those in the control group who were in supine position. They concluded that the semi fowler's position might be effective in enhancing the post-operative recovery score of the patients with laparoscopic abdominal surgery in the recovery room.

Association of hemodynamic parameters with the selected background variables among critically ill patients showed that there was no association between the hemodynamic parameters.

\section{Nursing Implications}

\section{Nursing practice}

Quality of nursing care could be improved by evidence based practice in nursing service especially in critical care unit. The study revealed a significant difference in systolic blood pressure in left lateral position and oxygen saturation in semi fowler's position when compared to other positions. The hemodynamic parameters were 
Citation: Anchala AM (2016) A Study to Assess the Effect of Therapeutic Positions on Hemodynamic Parameters among Critically III Patients in the Intensive Care Unit at Sri Ramachandra Medical Centre. J Nurs Care 5: 348. doi:10.4172/2167-1168.1000348

Page 6 of 8

\begin{tabular}{|c|c|c|c|c|c|}
\hline \multirow{2}{*}{ Demographic variables } & \multicolumn{2}{|c|}{$\mathrm{SpO}_{2}<96 \%$} & \multicolumn{2}{|c|}{$\mathrm{SpO}_{2} 96 \%-100 \%$} & \multirow{2}{*}{$x^{2}$ value and $p$ value } \\
\hline & No. & $\%$ & No. & $\%$ & \\
\hline $\begin{array}{l}\text { 1.Age in years } \\
\text { a. } 21-30 \\
\text { b. } 31-40 \\
\text { c. } 41-50 \\
\text { d. } 51-60 \\
\text { e. Above } 60\end{array}$ & $\begin{array}{l}0 \\
0 \\
1 \\
0 \\
0\end{array}$ & $\begin{array}{l}0 \\
0 \\
5 \\
0 \\
0\end{array}$ & $\begin{array}{l}4 \\
3 \\
1 \\
3 \\
8\end{array}$ & $\begin{array}{c}20 \\
15 \\
5 \\
15 \\
40\end{array}$ & $\begin{array}{l}9.474 \\
0.050 \\
\text { (N.S) }\end{array}$ \\
\hline $\begin{array}{l}\text { 2. Gender } \\
\text { a. Male } \\
\text { b. Female }\end{array}$ & $\begin{array}{l}1 \\
0\end{array}$ & $\begin{array}{l}5 \\
0\end{array}$ & $\begin{array}{c}16 \\
3\end{array}$ & $\begin{array}{l}80 \\
15\end{array}$ & $\begin{array}{c}0.186 \\
1.000 \text { (N.S) }\end{array}$ \\
\hline $\begin{array}{l}\text { 3. Occupation } \\
\text { a. Business } \\
\text { b. Homemaker } \\
\text { c. Retired } \\
\text { d. Professional }\end{array}$ & $\begin{array}{l}1 \\
0 \\
0 \\
0\end{array}$ & $\begin{array}{l}5 \\
0 \\
0 \\
0\end{array}$ & $\begin{array}{l}9 \\
3 \\
5 \\
2\end{array}$ & $\begin{array}{l}45 \\
15 \\
25 \\
10\end{array}$ & $\begin{array}{c}1.053 \\
0.789 \text { (N .S) }\end{array}$ \\
\hline $\begin{array}{l}\text { 4. Family Income per } \\
\text { month } \\
\text { a. Less than } 10,000 \\
\text { b. } 10,001-20,000 \\
\text { c. } 20,001-30,000 \\
\text { d. More than } 30,000\end{array}$ & $\begin{array}{l}0 \\
0 \\
1 \\
0\end{array}$ & $\begin{array}{l}0 \\
0 \\
5 \\
0\end{array}$ & $\begin{array}{l}1 \\
6 \\
8 \\
4\end{array}$ & $\begin{array}{c}5 \\
30 \\
40 \\
20\end{array}$ & $\begin{array}{c}1.287 \\
0.732 \text { (N.S) }\end{array}$ \\
\hline $\begin{array}{l}\text { 5. Residence } \\
\text { a. Urban } \\
\text { b. Rural } \\
\text { c. sub urban }\end{array}$ & $\begin{array}{l}0 \\
1 \\
0\end{array}$ & $\begin{array}{l}0 \\
5 \\
0\end{array}$ & $\begin{array}{c}12 \\
6 \\
1\end{array}$ & $\begin{array}{c}60 \\
30 \\
5\end{array}$ & $\begin{array}{c}1.955 \\
0.376 \text { (N.S) }\end{array}$ \\
\hline $\begin{array}{l}\text { 6. Education } \\
\text { a. Illiterate } \\
\text { b. Primary } \\
\text { c. Secondary } \\
\text { d. High school } \\
\text { e. Professional }\end{array}$ & $\begin{array}{l}0 \\
1 \\
0 \\
0 \\
0\end{array}$ & $\begin{array}{l}0 \\
5 \\
0 \\
0 \\
0\end{array}$ & $\begin{array}{l}1 \\
4 \\
8 \\
3 \\
3\end{array}$ & $\begin{array}{c}5 \\
20 \\
40 \\
15 \\
15\end{array}$ & $\begin{array}{c}3.158 \\
0.532 \text { (N.S) }\end{array}$ \\
\hline
\end{tabular}

Table 10: Association of demographic variables with post-test of oxygen saturation on semi fowler's position among study group ( $\mathrm{n}=20$ ).

\begin{tabular}{|c|c|c|c|c|c|}
\hline \multirow[b]{2}{*}{ Clinical variables } & \multicolumn{2}{|c|}{$\mathrm{SpO}_{2}<96 \%$} & \multicolumn{2}{|c|}{$\mathrm{SpO}_{2} 96 \%-100 \%$} & \multirow[b]{2}{*}{$X^{2}$ value and $P$ value } \\
\hline & No. & $\%$ & No. & $\%$ & \\
\hline $\begin{array}{l}\text { 1. Duration of ICU stay } \\
\text { a. } 1 \text { day } \\
\text { b. } 2 \text { days } \\
\text { c. } 3 \text { days }\end{array}$ & $\begin{array}{l}1 \\
0 \\
0\end{array}$ & $\begin{array}{l}5 \\
0 \\
0\end{array}$ & $\begin{array}{c}17 \\
1 \\
1\end{array}$ & $\begin{array}{c}85 \\
5 \\
5\end{array}$ & $\begin{array}{c}0.117 \\
0.943 \text { (N.S) }\end{array}$ \\
\hline $\begin{array}{l}\text { 2. Medication } \\
\text { a. Antibiotics } \\
\text { b. Anticoagulants } \\
\text { c. Any other }\end{array}$ & $\begin{array}{l}1 \\
0 \\
0\end{array}$ & $\begin{array}{l}5 \\
0 \\
0\end{array}$ & $\begin{array}{c}18 \\
1 \\
0\end{array}$ & $\begin{array}{c}90 \\
5 \\
0\end{array}$ & $\begin{array}{c}0.055 \\
1.814 \quad . S)\end{array}$ \\
\hline $\begin{array}{l}\text { 3. Body Mass Index } \\
\text { (Weight in } \mathrm{Kg} / \text { Height } \\
\text { in } \mathbf{~ m}^{2} \text { ) } \\
\text { a. Less than } 18 \\
\text { b. } 18.5-20 \\
\text { c. } 20.5-22 \\
\text { d. } 22.5-24 \\
\text { e. More than } 24.5\end{array}$ & $\begin{array}{l}0 \\
1 \\
0 \\
0 \\
0\end{array}$ & $\begin{array}{l}0 \\
5 \\
0 \\
0 \\
0\end{array}$ & $\begin{array}{l}2 \\
1 \\
1 \\
8 \\
7\end{array}$ & $\begin{array}{c}10 \\
5 \\
5 \\
40 \\
35\end{array}$ & $\begin{array}{c}9.474 \\
0.050 \text { (N.S) }\end{array}$ \\
\hline $\begin{array}{l}\text { 4. Diagnosis } \\
\text { a. Gastrointestinal } \\
\text { disorders } \\
\text { b. Renal diseases } \\
\text { c. Neurological } \\
\text { disorders } \\
\text { d. Diabetic ketoacidosis } \\
\text { e. Poisoning }\end{array}$ & $\begin{array}{l}0 \\
0 \\
1 \\
0 \\
0\end{array}$ & $\begin{array}{l}0 \\
0 \\
5 \\
0 \\
0\end{array}$ & $\begin{array}{l}6 \\
4 \\
3 \\
2 \\
4\end{array}$ & $\begin{array}{l}30 \\
20 \\
15 \\
10 \\
20\end{array}$ & $\begin{array}{c}1.053 \\
0.591 \text { (N.S) }\end{array}$ \\
\hline
\end{tabular}

NS=Non Significant

Table 11 represents the association of selected background variables with oxygen saturation on semi fowler's position among study group. There was no statistically significant difference between oxygen saturation and the selected background variables.

Table 11: Association of clinical variables with posttest of oxygen saturation on semi fowler's position among study group ( $\mathrm{n}=20$ ). 
Citation: Anchala AM (2016) A Study to Assess the Effect of Therapeutic Positions on Hemodynamic Parameters among Critically III Patients in the Intensive Care Unit at Sri Ramachandra Medical Centre. J Nurs Care 5: 348. doi:10.4172/2167-1168.1000348

Page 7 of 8

\begin{tabular}{|c|c|c|c|c|c|}
\hline \multirow[b]{2}{*}{ Demographic variables } & \multicolumn{2}{|c|}{$\mathrm{SpO}_{2}<96 \%$} & \multicolumn{2}{|c|}{$\mathrm{SpO}_{2} 96 \%-100 \%$} & \multirow[b]{2}{*}{$\begin{array}{l}X^{2} \text { value and } \\
P \text { value }\end{array}$} \\
\hline & No. & $\%$ & No. & $\%$ & \\
\hline $\begin{array}{l}\text { 1. Age in years } \\
\text { a. } 21-30 \\
\text { b. } 31-40 \\
\text { c. } 41-50 \\
\text { d. } 51-60 \\
\text { e. Above } 60\end{array}$ & $\begin{array}{l}1 \\
0 \\
4 \\
4 \\
7\end{array}$ & $\begin{array}{c}5 \\
0 \\
20 \\
20 \\
35\end{array}$ & $\begin{array}{l}0 \\
1 \\
0 \\
1 \\
2\end{array}$ & $\begin{array}{c}0 \\
5 \\
0 \\
5 \\
10\end{array}$ & $\begin{array}{l}5.278 \\
0.260 \\
\text { (N.S) }\end{array}$ \\
\hline $\begin{array}{l}\text { 2. Gender } \\
\text { a. Male } \\
\text { b. Female }\end{array}$ & $\begin{array}{l}9 \\
7\end{array}$ & $\begin{array}{l}45 \\
35\end{array}$ & $\begin{array}{l}1 \\
3\end{array}$ & $\begin{array}{c}5 \\
15\end{array}$ & $\begin{array}{c}1.250 \\
0.582 \text { (N.S) }\end{array}$ \\
\hline $\begin{array}{l}\text { 3. Occupation } \\
\text { a. Business } \\
\text { b. Homemaker } \\
\text { c. Retired } \\
\text { d. Professional }\end{array}$ & $\begin{array}{l}5 \\
7 \\
2 \\
2\end{array}$ & $\begin{array}{l}25 \\
35 \\
10 \\
10\end{array}$ & $\begin{array}{l}0 \\
3 \\
1 \\
0\end{array}$ & $\begin{array}{c}0 \\
15 \\
5 \\
0\end{array}$ & $\begin{array}{c}2.708 \\
0.439 \text { (N.S) }\end{array}$ \\
\hline $\begin{array}{l}\text { 4. Family Income per month } \\
\text { a. Less than } 10,000 \\
\text { b. } 10,001-20,000 \\
\text { c. } 20,001-30,000 \\
\text { d. More than } 30,000\end{array}$ & $\begin{array}{c}0 \\
0 \\
10 \\
6\end{array}$ & $\begin{array}{c}0 \\
0 \\
50 \\
30\end{array}$ & $\begin{array}{l}0 \\
0 \\
3 \\
1\end{array}$ & $\begin{array}{c}0 \\
0 \\
15 \\
5\end{array}$ & $\begin{array}{c}0.220 \\
0.639 \text { (N.S) }\end{array}$ \\
\hline $\begin{array}{l}\text { 5. Residence } \\
\text { a. Urban } \\
\text { b. Rural } \\
\text { c. sub urban }\end{array}$ & $\begin{array}{c}12 \\
0 \\
4\end{array}$ & $\begin{array}{c}60 \\
0 \\
20\end{array}$ & $\begin{array}{l}3 \\
1 \\
0\end{array}$ & $\begin{array}{l}15 \\
5 \\
0\end{array}$ & $\begin{array}{c}5.000 \\
0.082 \text { (N.S) }\end{array}$ \\
\hline $\begin{array}{l}\text { 6. Education } \\
\text { a. Illiterate } \\
\text { b. Primary } \\
\text { c. Secondary } \\
\text { d. High school } \\
\text { e. Professional }\end{array}$ & $\begin{array}{l}3 \\
7 \\
2 \\
2 \\
2\end{array}$ & $\begin{array}{l}15 \\
35 \\
10 \\
10 \\
10\end{array}$ & $\begin{array}{l}1 \\
1 \\
1 \\
1 \\
0\end{array}$ & $\begin{array}{l}5 \\
5 \\
5 \\
5 \\
0\end{array}$ & $\begin{array}{c}1.510 \\
0.825 \text { (N.S) }\end{array}$ \\
\hline
\end{tabular}

Table 12: Association of demographic variables with post-test of oxygen saturation in semi fowler's position among control group ( $\mathrm{n}=20$ ).

\begin{tabular}{|c|c|c|c|c|c|}
\hline \multirow[b]{2}{*}{ Clinical variables } & \multicolumn{2}{|c|}{$\mathrm{SpO}_{2}<96 \%$} & \multicolumn{2}{|c|}{$\mathrm{SpO}_{2} 96 \%-100 \%$} & \multirow{2}{*}{$\begin{array}{l}X^{2} \text { value and } \\
P \text { value }\end{array}$} \\
\hline & No. & $\%$ & No. & $\%$ & \\
\hline \multicolumn{6}{|l|}{ 1. Duration of ICU stay } \\
\hline $\begin{array}{l}\text { a. } 1 \text { day } \\
\text { b. } 2 \text { days } \\
\text { c. } 3 \text { days }\end{array}$ & $\begin{array}{c}14 \\
1 \\
1\end{array}$ & $\begin{array}{c}70 \\
5 \\
5\end{array}$ & $\begin{array}{l}4 \\
0 \\
0\end{array}$ & $\begin{array}{c}20 \\
0 \\
0\end{array}$ & $\begin{array}{c}0.556 \\
0.757 \text { (N.S) }\end{array}$ \\
\hline \multicolumn{6}{|l|}{ 2. Medication } \\
\hline $\begin{array}{l}\text { a. Antibiotics } \\
\text { b. Anticoagulants } \\
\text { c. Any other }\end{array}$ & $\begin{array}{l}12 \\
3 \\
1\end{array}$ & $\begin{array}{c}60 \\
15 \\
5\end{array}$ & $\begin{array}{l}4 \\
0 \\
0\end{array}$ & $\begin{array}{c}20 \\
0 \\
0\end{array}$ & $\begin{array}{c}1.250 \\
0.535 \text { (N.S) }\end{array}$ \\
\hline \multicolumn{6}{|c|}{$\begin{array}{l}\text { 3. Body Mass Index (Weight in } \mathrm{Kg} / \text { Height } \\
\text { in } \mathrm{m}^{2} \text { ) }\end{array}$} \\
\hline $\begin{array}{l}\text { a. Less than } 18 \\
\text { b. } 18.5-20 \\
\text { c. } 20.5-22 \\
\text { d. } 22.5-24 \\
\text { e. More than } 24.5\end{array}$ & $\begin{array}{c}1 \\
2 \\
2 \\
1 \\
10\end{array}$ & $\begin{array}{c}5 \\
10 \\
10 \\
5 \\
50\end{array}$ & $\begin{array}{l}0 \\
0 \\
0 \\
3 \\
1\end{array}$ & $\begin{array}{c}0 \\
0 \\
0 \\
15 \\
5\end{array}$ & $\begin{array}{c}9.631 \\
0.047 \text { (N.S) }\end{array}$ \\
\hline \multicolumn{6}{|l|}{ 4. Diagnosis } \\
\hline $\begin{array}{l}\text { a. Gastrointestinal disorders } \\
\text { b. Renal diseases } \\
\text { c. Neurological disorders } \\
\text { d. Diabetic ketoacidosis } \\
\text { e. Poisoning }\end{array}$ & $\begin{array}{l}4 \\
4 \\
4 \\
1 \\
3\end{array}$ & $\begin{array}{c}20 \\
\\
20 \\
20 \\
5 \\
15\end{array}$ & $\begin{array}{l}0 \\
1 \\
0 \\
1 \\
2\end{array}$ & $\begin{array}{c}0 \\
\\
5 \\
0 \\
5 \\
10\end{array}$ & $\begin{array}{c}1.364 \\
0.506 \text { (N.S) }\end{array}$ \\
\hline
\end{tabular}

NS=Non Significant

Table 13 represents the association of selected background variables with oxygen saturation on semi fowler's position among control group. There was no statistically significant difference between oxygen saturation and the selected background variables.

Table 13: Association of clinical variables with post-test of oxygen saturation on semi fowler's position among control group ( $n=20)$. 
assessed in both the groups and it showed the hemodynamic stability in various therapeutic positions. Semi fowler's position has more efficacies in improving oxygen saturation to prevent hypoxemia, desaturation and respiratory insufficiency. Therapeutic positions based on turning schedule have a significant role in maintaining the hemodynamic parameters and preventing complications.

\section{Nursing education}

This research study provides additional knowledge which will provoke the nursing theory. Nursing should be an evidence based quality care along with adequate theory based knowledge. Positioning is one of the essential procedures in intensive care unit and also for critical care nurses. Nurses should not only focus on concentrating in vital interventions but also in the prevention of risk occurrence.

Educating the efficacy of the study to the critical care nurses will improve professionalism and help to change the health care trend.

\section{Nursing administration}

Use of therapeutic positions based on turning schedule has more efficacies in maintaining the hemodynamic parameters and preventing the complications; having this concept in mind an administrator will prefer therapeutic positions for the critically ill patients.

\section{Nursing research}

In our country the practice of positioning the critically ill patients based on turning schedule is very minimal. This literature is to support the system which has to be developed through the related researches to improve the knowledge and create awareness with evidence. The nurse researchers should be able to conduct the research on therapeutic positions based on turning schedule in order to generate evidence based nursing practice.

\section{Recommendations}

1. The study can be replicated with larger samples.

2. A study can be carried on the aspects of knowledge, skill and attitude towards therapeutic positions among critical care nurses.

3. Similar study can be done on the aspect of preventing complications of immobility.

4. A study can be done on effect of left lateral position on systolic blood pressure among critically ill patients.

\section{Conclusion}

This study has attempted to identify the changes in hemodynamic parameters among critically ill patients while following turning schedule. The study shows that there was a significant difference in systolic blood pressure in left lateral position and oxygen saturation in semi fowler's position. Further research is needed to investigate the changes in hemodynamic parameters and the turning schedule.

\section{References}

1. Indu Khurana (2009) Textbook of medical physiology. (1sted). Philadelphia: Saunders Elsevier.

2. Fontaine DK, McQuillan K (1989) Positioning as a nursing therapy in trauma care. Crit Care Nurs Clin North Am 1: 105-111.

3. Bailey P, Thomsen GE, Spuhler VJ, Blair R, Jewkes J, et al. (2007) Early activity is feasible and safe in respiratory failure patients. Crit Care Med 35: 139-145. 